With both troatmonts the difference in slopes between insulin-treated and control cultures was significant at the level of 5 per cent, showing that insulin retarded the rate of turnover of carbon-14.

We thank Dr. W. Kwolek for his help in the statistical treatment of the data.

Biochemical Research Section,

\section{G. MelnyKovych}

P. A. Millek

Lederle Laboratories,

American Cyanamid Co.,

Pearl River, New York.

${ }^{2}$ Wallace, R., Davies, M. C., Pease, B., Englert, M., and Moyer, A. W., Proc. Soc. Exp. Biol. Med., 103, 845 (1960).

1 Eagle, H., Piez, K. A., Hleishman, R., and Oyama, V. T., J. Riol. Chem., 234, 592 (1959).

S Jordan, H. C., and Schmidt, P. A., Biochem. Biophys. Res. Comm., 4, 313 (1961).

\section{Effect of 6-Mercaptopurine on Carbo- hydrate Metabolism of Human Cancer Cells}

IN an investigation directed toward the evaluation of the relative effects of various chemothorapeutic chemicals or drugs on the carbohydrate metabolism of intact human cancer cells ${ }^{1}$, an unpredicted and unusual disappearance of glucose was notod when cells were incubated with 6-morcaptopurine. This effect was discernible under a variety of test conditions; incubation time varied from 1 to $3 \mathrm{hr}$.; cell concentrations varied from $60 \times 10^{6}$ to $230 \times 10^{6}$; chemical concontration varied from 5 to $50 \mu \mathrm{gm} . / 10^{6}$ cells. It was also discerniblo in all human coll types investigated; acute and chronic lymphatic leukæmia, acute and chronic myologenous leukæmia, and in ascites cells from patients with carcinoma of the ovaries. It is also readily demonstratod with tumour cell suspension obtainod from a transplantable (in Sprague-Dawley rats) chloromyeloid leukamia ${ }^{2}$. In all, this effect has been found without exception in some 30 separate examinations of human cancer cells.

In Table 1 are summarized the results of a typical experiment which demonstrates this unusual effect. The cells were obtained from a patient with sub-acute lymphatic leukæmia. The glucose utilized is the differenco between the glucose at zero time and the glucose in the flask at tho ond of the experiment as determined by the glucose oxidase test ${ }^{3}$. 'The glucose dissimilated is the sum of glucose equivalents used in respiration and glucose equivalonts of lactic acid produced; the latter was determined by a chemical method ${ }^{4}$. The excess of glucose dissimilated ovor the control value is due entirely to the stimulation of aerobic lactic acid production by the chemicals; except for nitrogen mustard which produced inhibition of lactic acid production. Tho quantitative effects caused by changes in respiration are almost negligible.

Table 1. Batanoe of GLUCOSF Utilization of Human LeURamic LEUCOOYTES IN HOMOLOGOUS PLASMA

Condition Chemical Glucose Glucose Differ-

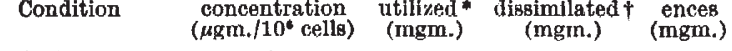

Control

Diazouracil 8-Azaguanine 6-Mercaptopurine Nitrogen mustard Triethylene thiophosphoramid

inleucoblastin xperiment

$t$ Sum of glucose equivalents used in respiration and glucose equivalents of lactic acid produced.
The broader aspects of these chemical effects will be published elsewhere 5 .

In the last column can be seen the unusual effoct produced by 6-mercaptopurine. This amount of glucoso represents more than 50 per cent of the glucose initially present. The effect of triethylene thiophosphoramide is worthy of noto. However, we have not observed this effect in all our work as we have with the 6-mercaptopurine.

It has been reported ${ }^{6}$ that 6-morcaptopurine causes an increased deposition of glycogen in the cells of Ehrlich ascites tumour obtained from mice givon intraperitoneal injections at $100 \mathrm{mgm}$. $/ \mathrm{kgm}$. for 4 days followed by intraperitoneal glucose injections. This group ${ }^{7}$ also report a concomitant inhibition of lactic dehydrogenase, undor thoir experimental conditions.

However, under the conditions of our experiments, short term and in vitro, lactic dehydrogonase inhibition is not evidenced based on the stimulation of aerobic lactic acid production.

It is possible that the immediate effect is on the hoxokinase roaction with subsequent disposition of the glucose-6-phosphate dependent on intracellular enzymatic conditions. The quantitative localization of this 'missing' glucose is under investigation in human and animal cancer tissues ${ }^{8}$.

Not to be overlooked is the fact that the specific stimulation of glucose uptake by 6-mercaptopurine offers a new approach to the control of diabetics.

This work was supported by grant $T \cdot .125 B$ of the American Cancer Socioty.

BernaRd J. KatchMan

ROBEYT E. ZIPF

JAMES P. F. MURPhy

Department of Rosearch,

Miami Valley Hospital, Dayton 9, Ohio.

Murphy, J. P. F., Zinf, R. E., Parrish, W. B., and Katchman, B. J., Clin. Chem., 7,568 (1961). Zipf, R. T., Chiles, L., Miller, M., and Katchman, B. J., J. Nat.
Cancer Inst., 22, 669 (1959).

McComb, R. B., and Yushok, W. D., J. Franklin Inst., 285, 417 (1958).

-Barkor, S. B., and Summerson, W. H., J. Biol. Chem., 138, 535 (1941).

${ }^{5}$ Katchman, B. J., Zipf, R. E., and Murphy, J. P. F. (in preparation).

- Peclle, A., Tessari, L., and Yamanoto, T., Giorn. Ital. Chemioterap., 6. 37 (1958); Chem. Abs., 64, 5936e (1960).
(1960)

"Yamamoto, T., Riva, G., and Tessari, L., Giorn. Ital. Chemioterap., 5, 33 (1958); Chem. Abs., 54, 5936c (1960).

\section{Effect of Pyridine Nucleotides on the I- ${ }^{14} \mathrm{C}$-Glucose Utilization of Normal Human Red Blood Cells}

A NUMBer of investigators have shown that disphosphopyridine nucleotide (DPN) and triphos. phopyridine nucleotide (TPN) enhance tho motabolism of glucose in liver preparations via the Embden-Meyerhof and pentose-phosphate (hexosemonophosphate) pathways, respectively ${ }^{1-3}$. Wo have found that TPN and roduced triphosphopyridino nucleotide (TPNH) stimulate the $1-14 \mathrm{C}$-glucose metabolism of normal human red blood cells as measurod by the increased production of ${ }^{14} \mathrm{CO}_{2}$ with increasing amounts of the pyridine nucleotides. Since normal human red blood cells contain an Embden-Meyerhof pathway but cannot oxidize pyruvate, the only source of carbon dioxide is from the decarboxylation of carbon-1 in the pentose-phosphate pathway. Therefore, ${ }^{14} \mathrm{CO}_{2}$ production is a measure of the 